\title{
Psychological and Mental Health Issues Due to COVID-19 Among Bangladeshi Tertiary Educational Institution Students
}

\author{
Hasanul Banna ${ }^{1}$ (D) Md Aslam Mia ${ }^{2}$ (D) Mark D. Griffiths ${ }^{3} \cdot$ Md Rabiul Alam $^{4}$. \\ Jannatul Ferdous ${ }^{5}$
}

Accepted: 10 August 2021 / Published online: 20 August 2021

(c) The Author(s), under exclusive licence to Springer Science+Business Media, LLC, part of Springer Nature 2021

Due to the rapid spread of the novel coronavirus disease-2019 (COVID-19), cases in Bangladesh have continued to increase with a total number of confirmed cases of over 1.04 million and over 16,842 deaths (as of July 14, 2021). Such a surge in COVID-19 cases has caused detrimental impacts in all areas of human lives including students of all levels. The economic and psychological costs to students in higher learning institutions in Bangladesh are believed to be very high compared to other demographic groups in the country (Islam et al., 2020) as a large proportion of expenditure (29\% of total education cost) is spent on private tutoring (Toaha, 2015). All the educational institutions in Bangladesh were (physically) closed since early March 2020 and will continue to be so until August 2021 (Ela et al., 2021; Xinhua, 2021).

Based on the infection rate of COVID-19 in Bangladesh, it is uncertain when these institutions are going to physically open and return to normal in-person teaching environment and the chances of higher education institutions opening in this calendar year appear quite unlikely. Moreover, the physical operation of all types of educational institutions depends on the discretion of the government which is constantly monitoring the situation. Consequently, this situation has created severe psychological and socioeconomic pressure among students enrolled at higher learning institutions (Faisal et al., 2021) because the prolonged closure will result in delayed graduation and depriving them of the opportunity to secure their desired jobs (Ela et al., 2021; Hossain et al., 2021). Here, we provide several explanations in an aim to better understand the situation and provide some guidelines to the respective authorities, particularly to the Ministry of Education in Bangladesh.

Hasanul Banna

banna@um.edu.my; bannaje@gmail.com

1 Ungku Aziz Centre for Development Studies, Faculty of Economics and Administration, Universiti Malaya, 50603 Kuala Lumpur, Malaysia

2 School of Management, Universiti Sains Malaysia, 11800 Penang, Malaysia

3 International Gaming Research Unit, Psychology Department, Nottingham Trent University, Burton Street, Nottingham NG1 4FQ, UK

4 Department of Language and Literacy Education, Faculty of Education, Universiti Malaya, 50603 Kuala Lumpur, Malaysia

5 Department of Public Administration, Comilla University, Cumilla 3506, Bangladesh 
Psychological pressure is the result of many other factors. For instance, economic despair, uncertainty about the future, lack of recreation, and other constraints can result in mental health concerns (e.g., depression, anxiety, stress, etc.). Due to the implementation of lockdown and spatial distancing policies, self-financing students enrolled at tertiary education institutions have had their private tutoring-based income badly affected (because they can no longer provide coaching services to school and college students for a monthly wage). The problem is so acute in Bangladesh because of very limited and highly competitive educational loans and bursaries for the students to meet both their living expenses and tuition fees. Charging full tuition fees by some private institutions amid the COVID-19 pandemic has aggravated the situation. On top of this, the online teaching methods adopted by some of the private universities have added extra financial costs to the students and their families because they have to pay for stable internet packages and have regular access to a laptop/desktop/smartphone (Ela et al., 2021; Islam et al., 2020). Additionally, the recent increase in government taxes imposed on internet service providers has increased the price of internet bundles, and many students and their families have found it costly and unaffordable (BDNEWS24, 2020).

The income generated from private tutoring/coaching services by higher learning institution students in Bangladesh is also partly used to support respective families financially (Ela et al., 2021; Faisal et al., 2021). Since the educational institutions are now physically closed and no tuition/coaching services are available, they cannot earn money to meet their own expense and support their families. This has, in turn, resulted in extra psychological pressure among students of higher learning institutions who were dependent on such income in the past but have been unable to earn money because of the lockdown (Business Standard, 2020a). Furthermore, private universities' students have to do more part-time jobs because they have to pay relatively higher tuition fees compared to public universities students. Public university students may face less economic pressure because the tuition fees at these universities are highly subsidized by the government and online teaching has yet to start (only a handful of public universities already started online teaching and learning).

Insufficient accommodation at public universities and almost non-existent housing at private universities in Bangladesh have forced many students to rent apartments/houses outside university premises. Although university dormitories are cheap and highly subsidised, many students (especially those who stay outside the campus) need to spend a relatively large amount of their income on house rent. Therefore, many students are dependent on their private tutoring-based earnings to pay for accommodation, but it has now become difficult because their earnings have been halted for more than a year. The unsettled rental debt by students recently resulted in a few incidents in Dhaka (the capital city) that sparked an online backlash when several owners of the houses/apartments threw the belongings of students into a nearby drain (Business Standard, 2020b). Such unexpected treatment across the country have put extra mental health pressure on students and has resulted in acute mental anguish, despair, and anxiety (Dhaka Tribune, 2020a). Consequently, the mental health of students should be ensured by the respective Bangladeshi authorities, particularly the Ministry of Education and the University Grants Commissions through the implementation of appropriate policies and mentoring.

Students in different universities were at various phases of their study at the time educational institutions physically closed due to the COVID-19 pandemic (some were in the middle of their study year and some of them were at the start of their final year). However, students at all levels and ages are experiencing mental stress thinking about their uncertain future (Ela et al., 2021; Daily Star, 2020). Final year students who were 
expected to finish their degrees and get a job have suffered the most. They are mentally anguished because many of them cannot complete their degrees on time due to the abrupt closure of their universities (Daily Star, 2020). Furthermore, recently graduated students have also experienced mental suffering because they are in search of jobs in a job market that has shrunk since the implementation of the countrywide lockdown (Ela et al., 2021). Moreover, students who are looking for government jobs may encounter mental pressures because a government job in Bangladesh has an age limit (except a few sectors, those over 30 years are unable to be employed) and many of them are on the verge of this age limit (Daily Campus, 2020).

It is evident that $85 \%$ of the labour force in Bangladesh is engaged in various informal occupational activities (e.g., wage labourers, self-employed individuals, unpaid family labour, piece-rate workers, and other hired labour) (SANEM, 2020). The pandemic has caused job losses to many parents which have subsequently impacted the study of their children studying at universities who have had to drop out because they cannot pay the fees (Faisal et al., 2021; Hossain et al., 2021). Some students have even committed suicide. For example, a student of a renowned Bangladeshi private university committed suicide along with his mother due to financial constraints and mental anguish (Dhaka Tribune, 2020b).

From what we have already outlined, it is evident that mental anguish along with other associated pressures of students in Bangladesh caused by the pandemic has been extremely unsettling. However, as the pandemic prolonged, students in higher learning institutions have been searching for ways to relieve their depression, anxiety, and mental anguish. Many strategies focus on reducing loneliness as this appears to be one of the main reasons to causing mental anguish. Many students have been engaged in different types of businesses run through virtual platforms and/or have started online tutoring to earn money. Some Bangladeshi tertiary level students are also engaged in different types of voluntary and social activities such as collecting financial donations from the rich and distributing among the needy, voluntary online teaching to poor students, donating blood, etc. all of which are done for the sake of social welfare and community development (Dutta \& Smita, 2020). Some students have been reported to be playing online videogames excessively as a way of coping with the pandemic (Ela et al., 2021; Faisal et al., 2021). Some of students have opened small businesses such as tea stall, grocery shops, etc. As one student at the Institute of Business Administration (University of Dhaka) told us:

"At the very outset of the pandemic, it was very challenging for me to pass time as it badly affected my mental health. Five of my friends studying in different universities, were looking for activities to engage us. We pooled a small amount of money together and opened a tea stall. I also started online tutoring to IBA aspirants. These activities make me mentally strong and more economically stable as I no longer need to ask money from my parents."

Some students have left the capital city because they could not afford their living costs and made alternative arrangements to survive and keep themselves engaged (Dutta \& Smita, 2020). For instance, one undergraduate student at the Asian University of Bangladesh, a renowned private university told us:

"At the beginning of the closure of our university, we thought it would reopen very shortly but it didn't. So, as a means of survival I started driving an Uber car. My other two friends went back to their village and started vegetable businesses in their local markets. Now I feel both mentally and economically relieved." 
All the activities initiated by students obviously have lessons for others about how to minimize anxiety at a time of great uncertainty. However, while most are engaged in positive activities to help them cope financially and psychologically, a minority of students are engaged in activities that might ultimately have more negative consequences (e.g., excessive gaming).

The COVID-19 pandemic has economically and mentally affected university students in Bangladesh. Therefore, relevant and need-based initiatives are required from various government ministries, particularly the Ministry of Education. In light of the current situation in Bangladesh, we propose several initiatives that may be helpful to minimize mental health pressure and other associated psychological consequences of the students in higher education institutions. First, an education loan (even short-term ones like those in other developed countries) by the Bangladesh government should be provided to students in need so that they can continue their studies. Secondly, universities (in particular, private universities) should not pressurize their students to pay their tuition fees during the pandemic. Instead, they should seek financial assistance from the government or use alternative funding (e.g., an endowment fund) to ensure their financial viability as implemented by one of the private universities (i.e., Northern University of Bangladesh declared a BDT 180 million (around US\$ 2.10 million) stimulus package (in the form of full and partial tuition fee waiver, which is funded by International Business Agriculture \& Technology Trust) for the welfare of the students (Business Standard, 2020c). Other universities could initiate this type of stimulus package so that students' learning does not get hampered and provides relief from the psychological pressure and other mental health issues they face.

Third, university teachers and relevant sections/institutions should continuously monitor student mental health and provide adequate support to the students (Goothy et al., 2020). Fourth, internet service providers should come forward and provide affordable internet rates for students of higher learning institutions to ensure virtual teaching and learning activities are seamless and efficient (Ela et al., 2021). Fifth, in terms of the age limit for government jobs, the Ministry of Education should collaborate with other ministries to re-review the current age limit for government jobs providing a much-needed leeway to the affected students (Ela et al., 2021). If the age limit cannot be extended permanently, it should at least be considered for the next couple of years.

Author contribution All authors made a significant contribution to the conception, design, execution, or interpretation of the reported communication.

\section{Declarations}

Originality and plagiarism This was the authors' original work and other authors' work has been appropriately cited or quoted.

Conflict of interest The authors declare no potential conflicts of interest with respect to the research, authorship, and/or publication of this article.

\section{References}

BDNEWS24. (2020). Budget spike in mobile phone service charges cause user outrage amid crisis. Accessed on 21 January 2021 from https://bdnews24.com/business/2020/06/13/budget-spike-inmobile-phone-service-charges-cause-user-outrage-amid-crisis. 
Business Standard. (2020a). Covid-19: Tutors, their dependent families in big trouble. Accessed on 21 January 2021 from https://tbsnews.net/bangladesh/education/covid-19-tutors-their-dependent-families-bigtrouble-73687.

Business Standard. (2020b). Two landlords' dumps students' certificates for due rent in the capital. Accessed on 21 January 2021 from https://tbsnews.net/bangladesh/districts/two-landlords-dumpsstudents-certificates-due-rent-capital-101335.

Business Standard. (2020c). NUB announces Tk18cr incentive package for students amid Covid-19. Accessed on 11 January 2021 from https://tbsnews.net/bangladesh/education/nub-announces-incen tive-package-students-amid-covid-19-87385.

Daily Campus. (2020). Age limit, no job advertisement and mental pressure during COVID-19 (In Bengali). Accessed on 27 January 2021 from https://www.thedailycampus.com/career/47848.

Daily Star. (2020). An uncertain future for students amidst Covid-19 outbreak. Accessed on 03 February 2021 from https://www.thedailystar.net/shout/news/uncertain-future-students-amidst-covid-19-outbr eak-1888648.

Dhaka Tribune. (2020a). Locked up for rent advance, 5 female students rescued in Bogra. Accessed on 15 February 2021 from https://www.dhakatribune.com/bangladesh/nation/2020/05/17/locked-up-for-rentadvance-5-female-students-rescued-in-bogra.

Dhaka Tribune. (2020b). Woman and her son end life over financial problems in Bogra. Accessed on 20 February 2021 from https://www.dhakatribune.com/bangladesh/nation/2020/06/11/woman-and-herson-end-life-over-financial-problems-in-bogra.

Dutta, S., \& Smita, M. K. (2020). The impact of COVID-19 pandemic on tertiary education in Bangladesh: Students' perspectives. Open Journal of Social Sciences, 8(9), 53.

Ela, M. Z., Shohel, T. A., Khan, L., Jahan, N., Hossain, M. T., \& Islam, M. N. (2021). Prolonged lockdown and academic uncertainties in Bangladesh: A qualitative investigation during the COVID-19 pandemic. Heliyon, 7(2), e06263.

Faisal, R. A., Jobe, M. C., Ahmed, O., \& Sharker, T. (2021). Mental health status, anxiety, and depression levels of Bangladeshi university students during the COVID-19 pandemic. International Journal of Mental Health and Addiction, 1-16. https://doi.org/10.1007/s11469-020-00458-y.

Goothy, S. S. K., Goothy, S., Choudhary, A., Potey, G. G., Purohit, M., Chakraborty, H., Pathak, A., \& Mahadik, V. K. (2020). COVID-19 lockdown impact on the mental health of students: Need to start a mental health cell. MOJ Anatomy \& Physiology, 7(2), 51-52. https://doi.org/10.15406/mojap.2020.07. 00289

Hossain, M. J., Ahmmed, F., Rahman, S. A., Sanam, S., Emran, T. B., \& Mitra, S. (2021). Impact of online education on fear of academic delay and psychological distress among university students following one year of COVID-19 outbreak in Bangladesh. Heliyon, 7(6). https://doi.org/10.1016/j.heliyon.2021. e07388.

Islam, M. A., Barna, S. D., Raihan, H., Khan, M. N. A., \& Hossain, M. T. (2020). Depression and anxiety among university students during the COVID-19 pandemic in Bangladesh: A web-based cross-sectional survey. PloS one, 15(8), e0238162.

SANEM. (2020). Thinking aloud: Volume VII, Issue 2. Accessed on 16 February 2021 from https://sanem net.org/thinking-aloudvol-vii-no-2/.

Toaha, A. S. M. (2015). Private tutoring and educational inequality: A study on selected coaching centers in Dhaka (Doctoral dissertation, University of Dhaka). Accessed on 13 March 2021 from http://repos itory.library.du.ac.bd:8080/handle/123456789/1525.

Xinhua. (2021). Bangladeshi educational institutions to remain closed till Feb. 28. Accessed on 28 April 2021 from http://www.xinhuanet.com/english/asiapacific/2021-02/14/c_139742696.htm.

Publisher's Note Springer Nature remains neutral with regard to jurisdictional claims in published maps and institutional affiliations. 